\title{
Kansas, Please Protect Our Children: Why Kansas Should Remove the Religious Exemption for Mandatory School Vaccinations
}

\author{
Kip Randall*
}

I. INTRODUCTION

On January 27, 2015, six-week-old DeAngelo passed away from whooping cough in Barton County, Kansas. ${ }^{1}$ DeAngelo was too young to vaccinate so he was relying on herd immunity-others being vaccinated - to protect him. ${ }^{2}$ DeAngelo was among four other cases of pertussis, more commonly known as whooping cough, in Barton County in January 2015; and cases were reported in Johnson County, McPherson County, and the city of Wichita as well. ${ }^{3}$ In response to DeAngelo's death and the other cases, the Barton County Health Department "urg[ed] [local] residents to make sure their whooping cough vaccines [were] up to date, or [to] get a booster if recommended."4 Specifically, Health Director Shelly Schneider singled out people with young children, urging

\footnotetext{
* University of Kansas School of Law, J.D. Candidate, 2016. United States Military Academy, B.S., 2006. I would like to thank my wife, Nicole, for bringing this topic to my attention and supporting me through the writing process. I would also like to thank Maureen Orth for her invaluable comments throughout the editing process and Professor John Peck and Matthew Rogers for their comments as well.

1. Devon Fasbinder, Whooping Cough Kills Six-Week-Old Boy in Barton County, KWCH-TV (posted Jan. 27, 2015, 9:47 PM; updated Jan. 30, 2015, 5:37 AM), http://www.kwch.com/news/local-news/Whooping-cough-kills-six-week-old-boy-in-BartonCounty/30955922.

2. Dan Diamond, Measles Is Just the Start: Whooping Cough Outbreaks-And Deaths-Are Rising, Too, Forbes (Feb. 4, 2015, 8:25 AM), http://www.forbes.com/sites/dandiamond/2015/02/04/measles-is-just-the-start-whooping-coughoutbreaks-are-on-the-rise-too/. Herd immunity is "the immunity or resistance to a particular infection that occurs in a group of people ... when a very high percentage of individuals have been vaccinated or previously exposed to the infection." Herd immunity, DICTIONARY.COM, http://dictionary.reference.com/browse/herd\%20immunity?s=t (last visited Mar. 29, 2016).

3. Mike Iuen, 1 Person Dies From Whooping Cough in Central Kansas, KAKE-TV (updated Jan. 27, 2015, 6:15 PM), http://www.kake.com/home/headlines/1-person-dies-from-whoopingcough-in-central-Kansas-289923241.html.
}

4. Id. 
parents to make sure those children were vaccinated. ${ }^{5}$ Unfortunately, whooping cough is not the only preventable health concern for Kansas children, and the Kansas legislature is not using its most powerful toolcompulsory vaccinations.

Outbreaks of vaccine-preventable diseases have spread across the United States. In 2014, the United States experienced a record number of measles cases (the highest since 2000) with 667 cases spreading across twenty-seven states. ${ }^{6}$ Included in those numbers were twentythree outbreaks, with the largest containing 383 cases. $^{7}$ In 2015 , there were 189 measles cases in twenty-four states. ${ }^{8}$ One hundred and fortyseven of those cases were part of the outbreak that started at Disneyland in California. ${ }^{9}$ In 2014 and 2015 combined, there were 2,280 cases of mumps in the United States. ${ }^{10}$ This disease was previously nearly eradicated. ${ }^{11}$ Moreover, the number of cases of pertussis increased in 2014 to 32,971 reported cases. ${ }^{12}$ Vaccinations against all three of these diseases, as well as diphtheria, hepatitis B, poliomyelitis, rubella, tetanus, and varicella, are required for students enrolling in Kansas schools. ${ }^{13}$ However, Kansas currently allows medical and religious exemptions from these mandatory vaccinations. ${ }^{14}$

Since Kansas enacted its first mandatory vaccination statute in 1961, Kansas's mandatory school vaccination law has included a religious exemption with its medical exemption. ${ }^{15}$ The current statute, Kansas Statute Annotated (K.S.A.) section 72-5209, grants medical exemptions

\footnotetext{
5. Id.

6. Measles Cases and Outbreaks, CENTERS fOR DiSEASE CONTROL AND PREVEntion, http://www.cdc.gov/measles/cases-outbreaks.html (last updated Mar. 8, 2016) [hereinafter CDC Measles Cases and Outbreaks].

7. $I d$.

8. Id.

9. Id.; Measles Outbreak Traced to Disneyland is Declared Over, NBC NEws (Apr. 17, 2015, 3:18 PM), http://www.nbcnews.com/storyline/measles-outbreak/measles-outbreak-traceddisneyland-declared-over-n343686.

10. Mumps Cases and Outbreaks, Centers for Disease Control and Prevention, http://www.cdc.gov/mumps/outbreaks.html (last updated Mar. 8, 2016) [hereinafter CDC Mumps Cases and Outbreaks].

11. Meryl Lin McKean, What's Up With Mumps?, Fox4News (posted Dec. 16, 2014, 5:48 PM; updated Dec. 17, 2014, 9:07 AM), http://fox4kc.com/2014/12/16/whats-up-with-mumps/.

12. Pertussis Outbreak Trends, Centers for Disease Control and Prevention, http://www.cdc.gov/pertussis/outbreaks/trends.html (last updated Sept. 8, 2015) [hereinafter $C D C$ Pertussis Outbreak Trends].

13. KAN. StAT. ANN. § 72-5209(a) (1994); KAN. AdMIN. REgS. § 28-1-20(b) (2009).

14. KAN. STAT. ANN. § 72-5209(b) (1994).

15. Schools-Health Programs-Health Tests and Inoculations; Alternatives, 94 OP. ATT'Y GEN. 162 (Kan. 1994), http://ksag.washburnlaw.edu/opinions/1994/1994-162.htm.
} 
when a physician certifies that the vaccination would "seriously endanger the life or health of the child." 16 Religious exemptions are granted when a parent certifies that the child is "an adherent of a religious denomination whose religious teachings are opposed to such [vaccinations]." ${ }^{17}$ Kansas is among forty-five other states and the District of Columbia that have such religious exemptions. ${ }^{18}$ Seventeen states also have a philosophical exemption, which lets a parent exempt their child based on the "moral, philosophical, or other personal beliefs" of the parent. ${ }^{19}$ In the entire United States, only Mississippi, West Virginia, and California have enacted legislation that have neither a religious nor a philosophical exemption. ${ }^{20}$ These three states only have a medical exemption. ${ }^{21}$

Since 1961, Kansas has not adequately protected its school-age children because parents may exempt their children from the vaccinations based on religious beliefs. To better protect its children, Kansas must pass legislation with only a medical exemption from mandatory vaccinations. Such legislation will not violate the Free Exercise Clause of the First Amendment or the Substantive Due Process Clause of the Fourteenth Amendment.

Because the purpose of this Comment is to persuade Kansas legislators to change the vaccination law, Section II discusses vaccination rates and statutes for the relevant states-Kansas, Mississippi, West Virginia, and California. Section III covers a brief history of the anti-vaccination movement. Section IV analyzes and applies the constitutional arguments against removing the religious exemption to Kansas. Finally, Section V explores proposed methods of dealing with exemptions and ultimately suggests that the best method for Kansas will be to remove its religious exemption.

\footnotetext{
16. KAN. STAT. ANN. § 72-5209(b)(1) (1994).

17. Id. $\S 72-5209(\mathrm{~b})(2)$.

18. State Information: Exemptions Permitted For State Immunization Requirements, IMMUNIZATION ACTION COALITION, http://www.immunize.org/laws/exemptions.asp (last updated Mar. 8, 2016).

19. Id.

20. $I d$.

21. $I d$.
} 


\section{STATE VACCINATION STATUTES}

\section{A. Kansas}

Three highly preventable diseases have practically run rampant in Kansas in recent years. The number of measles outbreaks in the United States has also skyrocketed in recent years, but Kansas's fight with the disease precedes the most recent outbreaks. Kansas had fourteen measles cases in 2014. ${ }^{22}$ Significantly, this was the first measles outbreak in Kansas City since $1996 .^{23}$ The numbers only get more dire from there. In 2012, the entire United States had just over fifty reported measles cases - and Kansas reported thirty-seven. ${ }^{24}$ Kansas's seventythree measles cases alone made up approximately one-third of all the 2011 reported measles cases in the United States. ${ }^{25}$ Within the last five years, measles has been significantly more prevalent in Kansas than in other states.

Kansas has also seen a large number of mumps cases. In 2014, Kansas only had two cases of mumps; but in 2012, Kansas's forty-one mumps cases made up nearly one-fifth of the cases in the country. ${ }^{26}$ In 2011, Kansas's eighty-two mumps cases made up more than one-fifth of the national total. ${ }^{27}$ The number of mumps cases in the United States has fluctuated drastically since 2010, but Kansas consistently reports higher numbers than most other states. ${ }^{28}$

The United States has seen a spike in pertussis cases, peaking in 2012 at 48,277, the most since $1955 .^{29}$ In 2015 , Kansas had 412 reported

22. Kan. DeP'T of Health and Env't, Cumulative Case Reports of Notifiable DISEASES (2014), http://www.kdheks.gov/epi/download/All_Disease_Counts_Summary_2014.pdf [hereinafter KDHE 2014 Summary].

23. Michael Mahoney, Missouri, Kansas Vaccination Rates Lag Behind Most States, KMBC.COM (updated Feb. 5, 2015, 5:29 PM), http://www.kmbc.com/news/missouri-kansasvaccination-rates-lag-behind-most-states/31118590.

24. KAN. DEP'T OF HEALTH AND ENV'T, REPORTABle INFECTIOUS DisEASES IN KANSAS 2012 SUMMARY (2012), http://www.kdheks.gov/epi/download/disease_summary/dissum12.pdf [hereinafter KDHE 2012 Summary]; CDC Measles Cases and Outbreaks, supra note 6.

25. Kan. DeP'T of Health And EnV'T, Reportable Diseases in Kansas 2011 Summary (2011), http://www.kdheks.gov/epi/download/disease_summary/dissum11.pdf [hereinafter KDHE 2011 Summary]; CDC Measles Cases and Outbreaks, supra note 6.

26. KDHE 2014 Summary, supra note 22; KDHE 2012 Summary, supra note 24; CDC Mumps Cases and Outbreaks, supra note 10.

27. KDHE 2011 Summary, supra note 25; CDC Mumps Cases and Outbreaks, supra note 10.

28. CDC Mumps Cases and Outbreaks, supra note 10.

29. CDC Pertussis Outbreak Trends, supra note 12. 
cases of pertussis. ${ }^{30}$ Additionally, Kansas was one of twenty-one states that had an increase in pertussis cases between 2013 and 2014. ${ }^{31}$

When one state is accounting for approximately one-fifth of the mumps cases some years and one-third or even one-half of the measles cases in the United States in other years, parents and legislators alike should take note of this red flag. In 2012, when Kansas's measles cases made up well over one-half of the nation's total cases and the mumps cases made up one-fifth of the nation's cases, Kansas's measles, mumps, and rubella (MMR) vaccination rate among children in kindergarten was just 90 percent. $^{32}$ In a state-by-state survey of vaccination rates, Kansas ranked forty-third because of that rate. Last year, Trust for America's Health published a news release on February 4, 2015, ranking Kansas thirty-ninth among the other states, with a MMR vaccination rate of 89.4 percent among preschool students. ${ }^{33}$ Kansas's vaccination rates are dismally lower than other states, and Kansas is reporting a much larger proportion of measles, mumps, and pertussis cases. These numbers indicate that Kansas is not adequately protecting its children under its current mandatory vaccination legislation.

In fact, Kansas has failed to adequately protect its children since the inception of its mandatory vaccination program in 1961. That year, the Kansas legislature enacted K.S.A. section 72-5381, its first mandatory vaccination statute, requiring that students entering school in the state for the first time present certification that they had received immunizations against certain diseases. ${ }^{34}$ The statute also included exemptions for medical and religious reasons, parental objection, and lack of means. ${ }^{35}$ The statute was amended several times between 1961 and 1993 when

30. Kan. DeP'T of Health And Env'T, Cumulative Case Reports of Notifiable DISEASES, http://www.kdheks.gov/epi/download/All_Disease_Counts_Summary_2015.pdf (last updated Mar. 12, 2016).

31. KDHE 2014 Summary, supra note 22; KAN. DEP'T OF HeALTH AND ENV'T, Cumulative

CASE REPORTS OF NOTIFIABLE DISEASES (2013), http://www.kdheks.gov/epi/download/All_Disease_Counts_Summary_2013.pdf; CDC Pertussis Outbreak Trends, supra note 12.

32. CEnTERs FOr Disease CONTROl AND PREVEntion, Morbidity AND Mortality WEEKLY REPORT (Aug. 2, 2013), http://www.cdc.gov/mmwr/preview/mmwrhtml/mm6230a3.htm.

33. Press Release: Measles Vaccination Rates for Preschoolers Below 90 Percent in 17 States, TRUST FOR AM.'s HEALTH (Feb. 2015), http://healthyamericans.org/newsroom/releases/?releaseid=323.

34. Schools-Health Programs-Health Tests and Inoculations; Alternatives, 94 OP. ATT'Y GEN. 162 (Kan. 1994), http://ksag.washburnlaw.edu/opinions/1994/1994-162.htm.

35. Id. 
K.S.A. section $72-5209$, the current statute, was finally adopted. ${ }^{36}$ The most notable of those amendments removed the parental objection exemption in 1965 and vested authority to determine required vaccinations in the Secretary of the Department of Health and Environment in $1978 .^{37}$ That amendment led to the adoption of Kansas Administrative Regulation (K.A.R.) section 28-1-20, which outlines the immunizations required for schools. ${ }^{38}$

Currently, K.S.A. section $72-5209$ and K.A.R. section 28-1-20 regulate the vaccinations required for children enrolling in Kansas schools. K.S.A. section $72-5209$ requires that:

\begin{abstract}
In each school year, every pupil enrolling or enrolled in any school for the first time in this state, and each child enrolling or enrolled for the first time in a preschool or day care program operated by a school, and such other pupils as may be designated by the secretary, prior to admission to and attendance at school, shall present to the appropriate school board certification from a physician or local health department that the pupil has received such tests and inoculations as are deemed necessary by the secretary by such means as are approved by the secretary.
\end{abstract}

K.A.R. section 28-1-20 states that the tests and inoculations deemed necessary by the secretary are "diphtheria, hepatitis B, measles (rubeola), mumps, pertussis (whooping cough), poliomyelitis, rubella (German measles), tetanus, and varicella (chickenpox)., ${ }^{, 40}$ However, K.S.A. section 72-5209(b) also provides two exemptions to these compulsory vaccinations: (1) a medical exemption when a vaccination "would seriously endanger the life or health of the child;" 41 and (2) a religious exemption when "the child is an adherent of a religious denomination whose religious teachings are opposed to such tests or inoculations." 42

This Comment suggests that vaccination rates are so low and the case numbers for measles, mumps, and pertussis are so high in Kansas because parents are given the ability to exempt their children from necessary and mandatory vaccines based on their religious beliefs. As a result, parents who exercise that exemption place their own children and

\footnotetext{
36. $I d$.

37. $I d$.

38. Id.

39. KAN. STAT. ANN. § 72-5209(a) (1994).

40. KAN. ADMIN. REGS. § 28-1-20 (2009).

41. KAN. STAT. ANN. § 72-5209(b)(1) (1994).

42. $§ 72-5209(\mathrm{~b})(2)$.
} 
other children at risk. However, rather than removing those exemptions as it should, the Kansas legislature is working in the wrong direction by trying to add another exemption.

K.S.A. section 72-5209 has not been amended since 1994. However, recently, the Kansas legislature has attempted to add a personal belief exemption. On January 26, 2011, the Kansas House of Representatives introduced a bill to amend K.S.A. section 72-5209 to include a philosophical exemption for "reasons of conscience or personal beliefs." ${ }^{43}$ On January 24, 2013, the Kansas Senate introduced a bill again to amend K.S.A. section 72-5209 to include a philosophical exemption. $^{44}$ Fortunately, both bills were referred to the Committee on Public Health and Welfare and subsequently died there. ${ }^{45}$ Consequently, the statute still contains only medical and religious exemptions. It is the religious exemption that continues to endanger the health of Kansas's children.

\section{B. Mississippi}

Comparing Mississippi's recent measles cases and vaccination rates with those of Kansas, the numbers are drastically different. Mississippi has not had a reported measles case since $1992 .{ }^{46}$ Additionally, during 2014, Mississippi had the highest MMR vaccination rate among kindergarteners in the United States at 99.7 percent. ${ }^{47}$ It follows that the outstanding vaccination rate and low number of measles cases are connected.

Now, contrast Mississippi's compulsory vaccination program for children entering school with Kansas's statute. Mississippi Code section

43. H.R. 2094, 2011-2012 Reg. Sess. (Kan. 2011); 2011-2012 Legislative Sessions: HB 2094, KAN. LEGISLATURE, http://www.kslegislature.org/li_2012/b2011_12/measures/hb2094/ (last visited Mar. 29, 2016).

44. S. 67, 2013-2014 Reg. Sess. (Kan. 2013); 2013-2014 Legislative Sessions: SB 67, KAN. LEGISLATURE, http://www.kslegislature.org/li_2014/b2013_14/measures/sb67/ (last visited Mar. 29, 2016).

45. Kansas 2011-2012 Legislative Sessions: HB 2094; Kansas 2013-2014 Legislative Sessions: SB 67.

46. News Release, Miss. State DeP'T OF Health (Aug. 21, 2008), http://msdh.ms.gov/msdhsite/_static/23,6891,341,517.html; Tony Yang, 2 States Haven't Had Measles Cases in Over 20 Years, THE FISCAL TIMES (Feb. 6, 2015), http://www.thefiscaltimes.com/2015/02/06/2-States-Haven-t-Had-Measles-Cases-Over-20-Years.

47. Todd C. Frankel, Mississippi - Yes, Mississippi - Has the Nation's Best Child Vaccination Rate. Here's Why., THE WASH. POST (Jan. 30, 2015), http://www.washingtonpost.com/news/storyline/wp/2015/01/30/mississippi-yes-mississippi-has-thenations-best-child-vaccination-rate-heres-why/. 
41-23-37 states that "it shall be unlawful for any child to attend any school, kindergarten or similar type facility intended for the instruction of children ...., either public or private ... unless they shall first have been vaccinated against those diseases specified by the state health officer." 48 The Mississippi State Department of Health requires vaccinations against diphtheria, tetanus, pertussis, polio, hepatitis B, measles, mumps, rubella, and varicella for students enrolling in school. ${ }^{49}$ Unlike Kansas, Mississippi does not allow a religious exemption. It allows an exemption only for medical reasons "when, in [the local health officer's] opinion, such exemption will not cause undue risk to the community." 50

The Mississippi statute previously included a religious exemption. In 1979, Charles Brown, the father of a six-year-old boy, challenged this religious exemption. ${ }^{51}$ The statute required a certification from an officer of the church that stated the "religious teachings require[d] reliance on prayer or spiritual means of healing" before a religious exemption would be granted. ${ }^{52}$ The minister of Brown's church provided a statement that the church "[did] not teach against the use of medecines, [sic] immunizations or vaccinations as prescribed by a duly [sic] physician." Thus, the school denied Brown's son admission and Brown sued, contending that the religious exemption violated the Free Exercise Clause of the First Amendment. ${ }^{54}$ On appeal, the Mississippi Supreme Court held that a statute requiring immunization against certain crippling and deadly diseases before a child could be admitted to school served a compelling public interest; to the extent that the statute conflicted with the religious beliefs of a parent, the interest of school children prevailed. ${ }^{55}$ The statute was reasonable and a constitutional exercise of police power. ${ }^{56}$

Despite the Mississippi Supreme Court's ruling in Brown, the Mississippi legislature has recently attempted to add a philosophical and a conscientious belief exemption. On January 4, 2011, Senate Bill 2017

\footnotetext{
48. Miss. Code ANN. § 41-23-37 (1983).

49. Mississippi School Immunization Requirements, Miss. State DeP’T of HeAlth (revised Jan. 12, 2015), http://www.msdh.state.ms.us/msdhsite/_static/resources/2029.pdf.

50. Miss. CODE ANN. § 41-23-37 (1983).

51. Brown v. Stone, 378 So.2d 218, 219 (Miss. 1979).

52. Id.

53. Id. at 219-20

54. Id. at 220 .

55. Id. at 223

56. Id.
} 
proposed an exemption if the immunization "conflicts with the philosophical beliefs of the parent or guardian." 57 That bill died in the Committee on Public Health and Welfare less than a month later. Then, on January 6, 2015, House Bill 130 proposed an exemption from a vaccination for conscientious beliefs. ${ }^{58}$ The Committee on Education substituted language within the bill that essentially removed that conscientious belief exemption, and the bill died on the calendar nine days later. ${ }^{59}$ It would be a grave mistake to add any type of non-medical exemption to the Mississippi mandatory vaccination program. Based on the number of Mississippi measles cases in recent years, a law without religious or personal belief exemptions better protects Mississippi's children.

\section{West Virginia}

When comparing West Virginia with Mississippi's recent measles cases and vaccination rates, one sees that the numbers are very similar. Like Mississippi, West Virginia has gone over two decades without a reported measles case. ${ }^{60}$ Also like Mississippi, in 2014, West Virginia had an extremely high MMR vaccination rate among kindergarteners, surpassed only by Mississippi in state rankings. ${ }^{61}$

West Virginia's compulsory vaccination statute also closely resembles Mississippi's. West Virginia's section 16-3-4 states that:

No child or person may be admitted or received in any of the schools of the state or a state-regulated child care center until he or she has been immunized against chickenpox, hepatitis-b, measles, meningitis, mumps, diphtheria, polio,, [sic] rubella, tetanus and whooping cough or produces a certificate from the commissioner granting the child or person an exemption from the compulsory immunization requirements

\footnotetext{
57. Senate Bill 2017, $2011 \quad$ Reg. Sess., MIss. LEG., http://billstatus.ls.state.ms.us/documents/2011/html/SB/2001-2099/SB2017IN.htm (last visited Mar. 29, 2016).

58. House Bill 130, $2015 \quad$ Reg. Sess., Miss. LEG., http://billstatus.ls.state.ms.us/documents/2015/html/HB/0100-0199/HB0130IN.htm (last visited Mar. 29, 2016).

59. HB 130: Mississippi House Bill, OPEN STATES, http://openstates.org/ms/bills/2015/HB130/ (last visited Mar. 29, 2016).

60. Amy Maxmen, Anti-Vaccination Movement Strikes Out in Bible Belt States, NewswEEK (June 19, 2014, 1:10 PM), http://www.newsweek.com/2014/06/27/anti-vaccination-crazies-strikeout-bible-belt-states-255483.html; Yang, supra note 46.

61. Frankel, supra note 47.
} 
of this section. $^{62}$

The statute allows a medical exemption only if "the physical condition of the child is such that immunization is contraindicated or there exists a specific precaution to a particular vaccine."63

In 2011, a little girl was denied admittance to West Virginia schools because her mother, Jennifer Workman, refused to have her vaccinated. ${ }^{64}$ Workman filed suit against the Mingo County Board of Education. ${ }^{65}$ On appeal to the Fourth Circuit, Workman argued that the mandatory immunization program violated her right to the free exercise of religion. ${ }^{66}$ The Court of Appeals applied strict scrutiny and found that West Virginia had a compelling interest to require children to be vaccinated before attending public school even if compulsory vaccination substantially burdened free exercise of religion. ${ }^{67}$

Like Mississippi, the West Virginia legislature recently introduced a bill that included an additional exemption. Senate Bill 286 was introduced on January 23, 2015. ${ }^{6}$ The new section contained a vaccination exemption if "[a] parent or guardian [has] a strongly held religious belief that his or her minor child or ward should not be subject to a required immunization." 69 However, like Mississippi, prior to being signed into law on March 31, 2015, the religious exemption language was removed. $^{70}$ Thus, also like Mississippi, West Virginia continues to protect its children by including only a medical exemption to mandatory vaccinations.

62. W. VA. CODE $§ 16-3-4(c)(2015)$.

63. Id. § 16-3-4(h)(1).

64. Workman v. Mingo Cty. Bd. of Educ., 419 F. App'x 348, 350 (4th Cir. 2011).

65. Id. at 351 .

66. Id. at 352 .

67. Id. at 353 .

68. S.B. 286, 82d Leg., Reg. Sess. (W. Va. 2015) (as introduced by Senate, Jan. 23, 2015); SB 286: West Virginia Senate Bill, OPEN STATES, http://openstates.org/wv/bills/2015/SB286/ (last visited Mar. 30, 2016).

69. S.B. 286, 82d Leg., Reg. Sess. (W. Va. 2015) (as introduced by Senate, Jan. 23, 2015); SB 286: West Virginia Senate Bill, OPEN STATES, http://openstates.org/wv/bills/2015/SB286/ (last visited Mar. 30, 2016).

70. S.B. 286, 82d Leg., Reg. Sess. (W. Va. 2015) (as adopted by Senate, Mar. 31, 2015); SB 286: West Virginia Senate Bill, OPEN STATES, http://openstates.org/wv/bills/2015/SB286/ (last visited Mar. 30, 2016). 


\section{California}

In December 2014, a multi-state measles outbreak that resulted in 173 reported cases originated in California's Disneyland. ${ }^{71}$ Following this outbreak, the California legislature took action to change its compulsory school vaccination statute. In doing so, California became the third state to have only a medical exemption. Prior to the recent approval of Senate Bill 277, California Health \& Safety Code 120335 provided that:

The governing authority shall not unconditionally admit any person as a pupil of any private or public elementary or secondary school, child care center, day nursery, nursery school, family day care home, or development center, unless, prior to his or her first admission to that institution, he or she has been fully immunized. The following are the diseases for which immunizations shall be documented: (1) Diphtheria. (2) Haemophilus influenzae type b. (3) Measles. (4) Mumps. (5) Pertussis (whooping cough). (6) Poliomyelitis. (7) Rubella. (8) Tetanus. (9) Hepatitis B. (10) Varicella (chickenpox).

Before 2015, California Health \& Safety Code 120325 allowed for a medical and personal belief exemption and California Health \& Safety Code 120365 outlined the requirements for the personal belief exemption. $^{73}$

On February 19, 2015, the California Senate introduced Senate Bill $277 .{ }^{74}$ It was signed into law on June 30,2015 , removing the personal belief exemption. ${ }^{75}$ Upon signing the bill, the California governor wrote a message to the Senate, which was read during the following day's session. ${ }^{76}$ According to the governor, he decided to sign the bill because " $[t]$ he science is clear that vaccines dramatically protect children against a number of infectious and dangerous diseases. While it's true that no medical intervention is without risk, the evidence shows that

71. CDC Measles Cases and Outbreaks, supra note 6; Disneyland Measles Outbreak Linked to Low Vaccine Rate, N.Y. DAILY NEWS (updated Apr. 6, 2015, 2:00 PM), http://www.nydailynews.com/life-style/health/disneyland-measles-outbreak-linked-vaccine-ratearticle-1.2151859.

72. CAL. Health \& SAFETy CODE $§ 120335$ (b) (West 2012).

73. CAL. HEALth \& SAFETy CODE $\S \S 120325$ (c), 120365 (West 1995).

74. $S B$ 277: California Senate Bill, OPEN STATES, http://openstates.org/ca/bills/20152016/SB277/ (last visited Mar. 30, 2016).

75. Id.; S. 277, 2015-2016 Reg. Sess. (Cal. 2015).

76. S. Journal, 2015-2016 Reg. Sess., at 1710 (Cal. 2015). 
immunization powerfully benefits and protects the community."77 Thus, California joined the ranks of Mississippi and West Virginia as states that provide no religious or personal belief vaccination exemptions. With some states taking such dramatic and effective steps to protect their children, why is Kansas not following their lead?

\section{HISTORY OF ANTI-VACCINATION MOVEMENT}

The California governor may have believed the science behind vaccines was clear, but not everyone in California agreed. Consequently, the four months from the introduction to signing of Senate Bill 277 were fraught with heated debates from opponents and proponents of mandatory vaccinations. The governor even referenced the "widespread interest and controversy" in his signing message. ${ }^{78}$ The controversy is due in large part to the studies of a man named Andrew Wakefield. To be sure, other public interest groups like California Chiropractic Association and A Voice for Choice also opposed California Senate Bill 277, but it is Andrew Wakefield who has led the anti-vaccination movement. $^{79}$

\section{A. Opponents: Vaccination is a Parental Choice}

Andrew Wakefield is perhaps the most well-recognized face of the anti-vaccination movement. In 1998, then-Dr. Wakefield published a study in which he allegedly linked the MMR vaccine to Crohn's disease and autism. ${ }^{80}$ For a decade following the publication, further studies

77. Id.

78. Id.

79. CAL. Chiropractic Ass'N, https://www.calchiro.org (last visited Mar. 30, 2016); A Voice FOR CHOICE, http://avoiceforchoice.org (last visited Mar. 30, 2016); On Heels of SB 277 PassageAnother Study Shows Vaccines are Safe, DR. Richard Pan: CaL. STATe Senator (July 8, 2015), http://sd06.senate.ca.gov/news/2015-07-08-heels-sb-277-passage-\%E2\%80\%93-another-studyshows-vaccines-are-safe [hereinafter On Heels of SB 277 Passage].

80. A.J. Wakefield, S.H. Murch, A. Anthony, J. Linnell, D.M. Casson, M. Malik, M. Berelowitz, A.P. Dhillon, M.A. Thomson, P. Harvey, A. Valentine, S.E. Davies \& J.A. SmithWalker, RETRACTED: Ileal-Lymphoid-Nodular Hyperplasia, Non-Specific Colitis, and Pervasive Development Disorder in Children, 351 THE LANCET 637, No. 9103 (1998), http://www.thelancet.com/journals/lancet/article/PIIS0140-6736(97)11096-0/abstract [hereinafter Redacted Lancet Article]; Stav Ziv, Andrew Wakefield, Father of the Anti-Vaccine Movement, Responds to the Current Measles Outbreak for the First Time, NEWSWEEK (Feb. 10, 2015, 7:08 AM), http://www.newsweek.com/2015/02/20/andrew-wakefield-father-anti-vaccine-movementsticks-his-story-305836.html. 
failed to find any link between the MMR vaccine and autism. ${ }^{81}$ The study was discredited and retracted by the publication, and Wakefield lost his medical license, but the damage was already done. ${ }^{82}$ Wakefield's study launched the anti-vaccination movement in the United States. ${ }^{83}$ The National Consumers League conducted a study that showed that 33 percent of parents with children under the age of eighteen and 29 percent of all adults believe that vaccinations cause autism. ${ }^{84}$ In the press release about the study, the executive director of NCL said, "[t]he antivaccination movement that has gained so much momentum in recent years is doing real, measurable damage to the health of our communities." 85

Despite that, there are at least ten subsequent studies showing absolutely no link between the MMR vaccine and autism, yet people continue to use that "link" as a reason to oppose mandatory vaccinations. ${ }^{86}$ Consequently, opponents of mandatory vaccinations and California Senate Bill 277 specifically are continuing to be quite vocal. ${ }^{87}$ Robert F. Kennedy Jr. spoke out against the bill by talking about his perceived effects on children. ${ }^{88}$ He said, "[t] hey get the shot, that night they have a fever of 103, they go to sleep, and three months later their brain is gone... . This is a holocaust, what this is doing to our country." 89

\section{B. Proponents: Vaccinations Are Necessary to Protect the Health and}

\footnotetext{
81. Fiona Godlee, Jane Smith \& Harvey Marcovitch, Wakefield's Article Linking MMR Vaccine and Autism Was Fraudlent, THE BMJ (Mar. 15, 2011), http://www.bmj.com/content/342/bmj.c7452.full; Ziv, supra note 80; Redacted Lancet Article, supra note 80 .

82. Godlee et al., supra note 81; Ziv, supra note 80; Redacted Lancet Article, supra note 80.

83. Ziv, supra note 80; Michael Specter, Autism, Vaccines, and The Lancet, NEw YORKER (Feb. 2, 2010), http://www.newyorker.com/news/news-desk/autism-vaccines-and-the-lancet.

84. Ziv, supra note 80; Survey: One Third of American Parents Mistakenly Link Vaccines to Autism, NAT'L CONSUMERS LEAGUE (Apr. 2, 2014), http://www.nclnet.org/survey_one_third_of_american_parents_mistakenly_link_vaccines_to_autism

85. Survey: One Third of American Parents Mistakenly Link Vaccines to Autism, NAT'L CONSUMERS LEAGUE (Apr. 2, http://www.nclnet.org/survey_one_third_of_american_parents_mistakenly_link_vaccines_to_autism

86. Specter, supra note 83 .

87. Jeremy B. White, From Death Threats to Holocaust Warning, California Vaccine Bill an Extraordinary Fight, THE SACRAMENTO BEE (June 30, 2015, 5:01 PM), http://www.sacbee.com/news/politics-government/capitol-alert/article25909216.html.

88. Id.

89. $I d$.
} 


\section{Welfare of Our Children}

Proponents of mandatory vaccination and California Senate Bill 277 continue to fight against Andrew Wakefield's claims. ${ }^{90}$ Within approximately a week of the signing of Senate Bill 277, Dr. Pan, a California State Senator and co-author of Bill 277, issued a press release regarding a RAND report on vaccines and their side effects. ${ }^{91}$ The report stated that:

The vaccines administered to U.S. children are very safe, and serious side effects are extremely rare, according to a new study published in the journal Pediatrics. The findings should help to debunk the myth that vaccines cause autism and other disorders - a claim that has led parents to avoid or delay vaccinations and has triggered a resurgence of diseases, such as measles and pertussis, that U.S. health officials had long considered to be under control. ${ }^{92}$

The RAND report went on to present the findings of researchers. ${ }^{93}$ First, the researchers found "strong evidence confirming that the [MMR] vaccine is not associated with autism in children." 94 Second, they found "strong evidence that several common vaccines for children-MMR, diphtheria, tetanus, and acellular pertussis (DTap), tetanus-diphtheria (Td), Haemophilus influenzae type b (Hib), and hepatitis B-are not associated with childhood leukemia." 95 Despite reports such as this, critics of Dr. Pan and other proponents of mandatory vaccinations continue to be drawn to Wakefield's fallacies about vaccination risks.

\section{CONSTITUTIONAL ARgUMENTS: COMPULSORY VACCINATIONS ARE CONSISTENT WITH THE FREE EXERCISE ClAUSE AND THE DUE PROCESS Clause}

The compulsory vaccination cases of Mississippi and West Virginia, Brown and Workman, respectively, provide a preview of the

90. Vaccinate CaL., http://www.vaccinatecalifornia.org (last visited Mar. 30, 2016); On Heels of SB 277 Passage, supra note 79.

91. On Heels of SB 277 Passage, supra note 79.

92. Margaret A. Maglione, Lopamudra Das, Laura Raaen, Alexandria Smith, Ramya Chari, Sydne Newberry, Roberta M. Shanman, Tanja Perry, Matthew Bidwell Goetz \& Courtney A. Gidengil, U.S. Vaccines Deemed Extremely Safe, with Serious Side Effects Rare Among Children, RAND CORP. (2014), http://www.rand.org/pubs/research_briefs/RB9799.html.

93. Id.

94. Id.

95. Id. 
constitutional challenges to compulsory vaccinations and their exemptions. To understand these arguments, one must first turn to the constitutional clauses themselves. The First Amendment of the United States Constitution provides that "Congress shall make no law... prohibiting the free exercise [of religion]." 96 Parents have used this clause to challenge the constitutionality of compulsory vaccinations when the state statute does not allow religious exemptions. ${ }^{97}$ The Due Process Clause of the Fourteenth Amendment provides that no State shall "deprive any person of life, liberty, or property, without due process of law." "98 Parents have claimed that mandatory vaccinations violated their children's substantive due process rights because "the right to refuse medical treatment is assumed to be part of liberty protected under the Due Process Clause." $" 99$

Recent cases reveal a conflict between parents' desire to make decisions regarding vaccinating their children and a state's interest in the welfare of its children. In Diana H. v. Rubin, ${ }^{100}$ the Arizona Court of Appeals faced the question of whether the parent of a dependent child has the right to prohibit state-directed immunization because of the parent's religious belief. ${ }^{101}$ The Arizona Court of Appeals concisely summarized the United States Supreme Court's holdings on the issue. ${ }^{102}$ First, it stated that "[i]t is beyond debate that parents have a fundamental liberty interest protected by the Fourteenth Amendment 'in the care, custody, and management' of their children." interest, and protected by the Free Exercise Clause, is the "right of parents to guide the religious upbringing of their children."104 The Diana $H$. court went on to cite the Arizona Supreme Court stating, "[b]ut those rights are not absolute. "The state has an interest in the welfare and health of children." 105 Therefore, "if the welfare of the child is seriously

\footnotetext{
96. U.S. CONST. amend. I.

97. See Workman v. Mingo Cty. Bd. of Educ., 419 Fed. App’x. 348, 352 (4th Cir. 2011) (arguing that the mandatory immunization program violated Plaintiff's right to the free exercise of religion).

98. U.S. CONST. amend. XIV, § 1.

99. Boone v. Boozman, 217 F. Supp. 2d 938, 955 (E.D. Ark. 2002) (citing Cruzan v. Dir., Mo. Dep't of Health, 497 U.S. 261, 278-79 (1990)), appeal dismissed sub nom. McCarthy v. Ozark Sch. Dist., 359 F.3d 1029 (8th Cir. 2004).

100. Diana H. v. Rubin, 171 P.3d 200 (Ariz. Ct. App. 2007).

101. Id. at 203 .

102. Id.

103. Id. (citing Santosky v. Kramer, 455 U.S. 745, 753 (1982)).

104. Id. (citing Wisconsin v. Yoder, 406 U.S. 205, 213-14 (1972)).

105. Id. (quoting In re Cochise Cty. Juvenile Action No. 5666-J, 650 P.2d 459, 463 (Ariz.
} 
jeopardized," the interest of the state is great enough that it may invade the rights of the parent. ${ }^{106}$

When the Tenth Circuit Court of Appeals heard PJ ex rel. Jenson $v$. Wagner, ${ }^{107}$ the appeal of a minor child and her parents regarding a section 1983 action involving a legal dispute of the child's medical care, the Tenth Circuit came to the same conclusion as the Arizona Court of Appeals. ${ }^{108}$ The Tenth Circuit noted that " $[t]$ he Supreme Court has long recognized ... that parental rights, including any right to direct a child's medical care, are not absolute." 109 "Accordingly, when a child's life or health is endangered by her parents' decisions, in some circumstances a state may intervene without violating the parents' constitutional rights." "The state may intervene because of its police power and because religious exemptions are not mandated by the Free Exercise Clause.

\section{A. Compulsory Vaccinations Are Within the Police Power of the State}

When discussing the constitutionality of exemptions or lack thereof, it is necessary to first discuss whether compulsory vaccinations themselves are constitutional. Two cases heard by the United States Supreme Court in the early 1900s are still good law on the constitutionality of compulsory vaccinations. First, in 1905, the Court heard Jacobson v. Massachusetts. ${ }^{111}$ The issue was a Massachusetts statute allowing a town's board of health to require the vaccination of its inhabitants as it saw necessary. ${ }^{112}$ During a smallpox outbreak, Cambridge's Board of Health required smallpox vaccinations of all its inhabitants. ${ }^{113}$ Jacobson challenged the constitutionality of the statute, but the Court found the statute to be within the state's police power. ${ }^{114}$ First, the Court noted that "[a]ccording to settled principles, the police

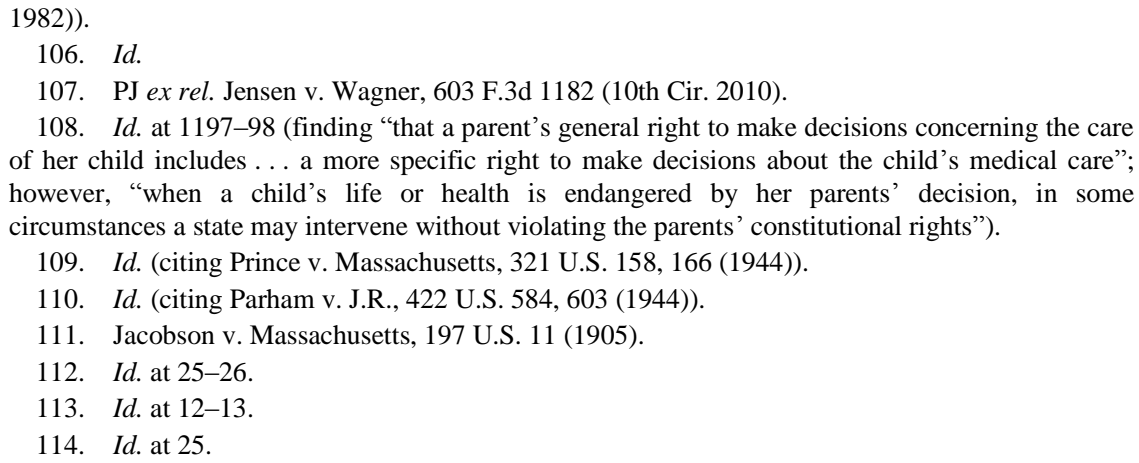


power of a state must be held to embrace, at least, such reasonable regulations established directly by legislative enactment as will protect the public health and the public safety." 115 The Court then went on to state that:

This court has more than once recognized it as a fundamental principle that persons and property are subjected to all kinds of restraints and burdens in order to secure the general comfort, health, and prosperity of the state; of the perfect right of the legislature to do which no question ever was, or upon acknowledged general principles ever can be, made, so far as natural persons are concerned.

Then, in 1922, the Court heard Zucht v. King. ${ }^{117}$ Zucht brought suit against San Antonio officials because she was excluded from public and private schools within the city. ${ }^{118}$ A San Antonio ordinance provided that no child or other person shall attend a public school or other place of education without having first presented a certificate of vaccination. ${ }^{119}$ Zucht refused to receive the vaccination and claimed the ordinance deprived her of her liberty without due process of law. ${ }^{120}$ The Court quickly dismissed the case by stating that "[1]ong before this suit was instituted, Jacobson v. Massachusetts had settled that it is within the police power of a state to provide for compulsory vaccinations." ${ }^{21}$ Furthermore, "[a] long line of decisions by this court had also settled that in the exercise of the police power reasonable classification may be freely applied, and that regulation is not violative of the equal protection clause merely because it is not all-embracing." 122 Both cases make it very clear that compulsory vaccinations are within the police power of the state.

\section{B. Religious Exemptions are not Mandated by the Free Exercise Clause}

Because the Supreme Court has held that compulsory vaccinations are within the police power of the state, the question is whether a state statute without religious exemptions violates the Free Exercise and

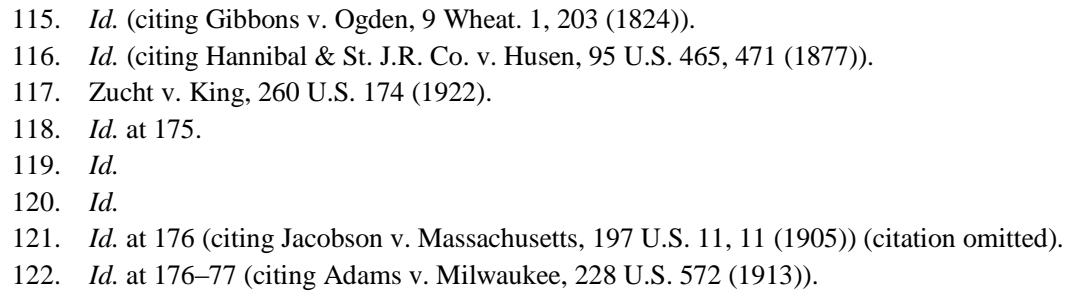


Substantive Due Process Clauses. Although many of the cases discussed below include arguments under both of these clauses, this Comment will split the arguments and address them separately.

1. Circuit Courts Have Held that Mandatory Vaccinations Without

Religious Exemptions Do Not Violate the Free Exercise Clause

The Eastern District of New York analyzed the constitutionality of religious exemptions under the Free Exercise Clause in two cases: Caviezel v. Great Neck Public School ${ }^{123}$ and Phillips v. City of New York. ${ }^{124}$ In Caviezel, the parents of a minor child challenged the constitutionality of New York's religious exemption to mandatory vaccinations under the Free Exercise Clause. ${ }^{125}$ The parents' challenge arose when their child was denied enrollment in pre-school because their application for religious exemption from vaccinations did not have a "genuine and sincere religious objection.","

In Phillips, two parents received religious exemptions from New York's mandatory vaccination program for their children. ${ }^{127}$ However, their children were excluded from school whenever there was a report of a vaccine-preventable disease. ${ }^{128}$ They sued, claiming the vaccination program denied their children the constitutional right to free exercise of religion. ${ }^{129}$ While ruling on these cases, the Eastern District of New York determined that the Second and Fourth Circuits have held that mandatory vaccinations without religious exemptions do not violate the Free Exercise Clause.

\section{a. Caviezel v. Great Neck Public School}

In Caviezel v. Great Neck Public School, ${ }^{130}$ the district court addressed the case law between 1905 and 2010 regarding compulsory

\footnotetext{
123. Caviezel v. Great Neck Public Sch., 739 F. Supp. 2d 273 (E.D.N.Y. 2010), aff'd, 500 F. App'x 16, (2d Cir. 2012).

124. Phillips v. City of New York, 27 F. Supp. 3d 310 (E.D.N.Y. 2014), aff'd, 775 F.3d 538 (2d Cir. 2015).

125. Caviezel, 739 F. Supp. 2d at 275-76.

126. Id. at 275.

127. Phillips, 27 F. Supp. 3d at 311.

128. Id.

129. Id. at 312 .

130. Caviezel, 739 F. Supp. 2d at 273.
} 
vaccinations and the Free Exercise Clause challenge. ${ }^{131}$ First, the court noted that the First Amendment of the Constitution provides that "Congress shall make no law prohibiting the free exercise [of religion]."132 "This prohibition applies to the states [through] Fourteenth Amendment incorporation." 133 The court then went on to state that "[n]either the United States Supreme Court nor the Court of Appeals for the Second Circuit has directly addressed whether a religious objector is constitutionally exempt from a program of mandatory vaccination."134 However, the Caviezel court believed that the Supreme Court has strongly suggested that no exemption need exist, and it began its analysis with Supreme Court cases. ${ }^{135}$

The Caviezel court decided that the Supreme Court cases indicate mandatory vaccinations do not violate the Free Exercise Clause. Beginning with Jacobson, as the oldest case on the issue, the Caviezel court noted that the Supreme Court upheld the Massachusetts law requiring the smallpox vaccination, but the Court did not address whether a religious objector could be exempt from mandatory vaccinations. ${ }^{136}$ The Caviezel court next cited Prince v. Massachusetts ${ }^{137}$ on the issue. ${ }^{138}$ Although Prince had not involved mandatory vaccinations, the Prince Court had stated in dicta that "the family itself is not beyond regulation in the public interest, as against a claim of religious liberty. ... The right to practice religion freely does not include liberty to expose the community or the child to communicable disease or the latter to ill health or death." 139 The Caviezel court pointed out that Prince had suggested that a state does not need to provide an exemption based on religious objections, but that the Supreme Court had not addressed the issue since then. ${ }^{140}$ However, the Caviezel court noted that the Supreme Court has mentioned religious exemptions two other times in Wisconsin v. Yoder ${ }^{141}$ and Employment Division, Department of

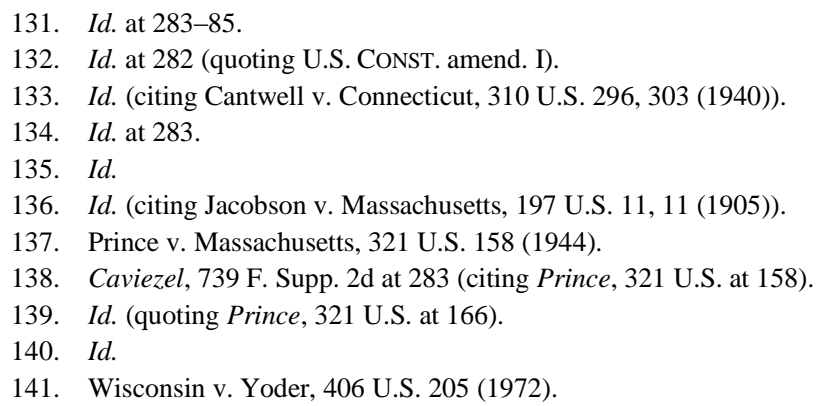


Human Resources of Oregon v. Smith. ${ }^{142}$ These were two very influential cases involving the Free Exercise Clause. ${ }^{143}$ Both times the Court had indicated that no exemption need exist. ${ }^{144}$

First, in Yoder, the case in which the Court had exempted Amish children from Wisconsin's compulsory education law, the Court stated that " $[\mathrm{t}]$ his case, of course, is not one in which any harm to the physical or mental health of the child or to the public safety, peace, order, or welfare has been demonstrated or may be properly inferred." 145 The Supreme Court continued by citing to Jacobson and indicating that religious exemptions from mandatory vaccinations would be granted "less readily than religious-based exemptions from compulsory education." 146 Then, in Employment Division, the Supreme Court listed compulsory vaccination laws as laws that "should not be required to be justified by a 'compelling state interest', even if it adversely affected the practice of religion." 147

After the Caviezel court analyzed Supreme Court decisions, it looked at federal district court rulings and decided that most courts agreed that the Supreme Court has strongly suggested that no exemption exists. At the time Caviezel was at the district court level, the Fourth Circuit had not yet heard Workman. Thus, the Caviezel court examined Workman's district court holding that "the First Amendment provides no right to a religious exemption from mandatory school immunizations." 148 Aside from mentioning Workman, the Caviezel court also mentioned three other federal district court opinions: Boone v. Boozman, McCarthy v. Boozman, and Sherr v. Northport-East Northport Union Free School District. ${ }^{149}$ Boone and McCarthy both arose out of Arkansas, and both

\footnotetext{
142. Emp't Div., Dep't of Human Res. of Or. v. Smith, 494 U.S. 872 (1990).

143. Caviezel, 739 F. Supp. 2d at 283-84 (citing Yoder, 406 U.S. at 230; Emp't Div., 494 U.S. at 889).

144. Id. at 283 .

145. Id. at 283-84 (quoting Yoder, 406 U.S. at 230).

146. Id. (citing Yoder, 406 U.S. at 230; Jacobson v. Massachusetts, 197 U.S. 11, 11 (1905)).

147. Id. (citing Emp't Div., 494 U.S. at 889).

148. Id. at 284 (citing Workman v. Mingo Cty. Sch., 667 F. Supp. 2d 679, 689 (S.D. W. Va. 2009)). When the Fourth Circuit heard Workman on appeal, it went so far as to find that "the state's wish to prevent the spread of communicable diseases clearly constitute[d] a compelling interest" so it withstood strict scrutiny. Workman v. Mingo Cty. Bd. of Educ., 419 F. App'x 348, 353 (4th Cir. 2011).

149. Caviezel, 739 F. Supp. 2d at 284 (citing McCarthy v. Boozman, 212 F. Supp. $2 d 945$ (W.D. Ark. 2002), appeal dismissed sub nom. McCarthy v. Ozark Sch. Dist., 359 F.3d 1029 (8th Cir 2004); Boone v. Boozman, 217 F. Supp. 2d 938 (E.D. Ark. 2002), appeal dismissed sub nom. McCarthy v. Ozark Sch. Dist., 359 F.3d 1029 (8th Cir. 2004); Sherr v. Northport-East Northport Union Free Sch. Dist., 672 F. Supp. 81 (E.D.N.Y. 1987)).
} 
courts also held that "the First Amendment provide[d] no right to a religious exemption from mandatory school immunizations." 150 The Sherr court went a step further and held that no constitutional right to religious exemptions exists and found that the statutory exemption New York provides to be "go[ing] beyond what the Supreme Court has declared the First Amendment to require." 151 These other district courts seem to agree with the Caviezel court that the Supreme Court has strongly suggested that no exemption need exist.

The plaintiffs in Caviezel presented two new arguments that allowed the court to more completely analyze the free exercise issue. The first argument was that the court should apply strict scrutiny to the state immunization requirement based on the Supreme Court's ruling in Church of the Lukumi Babalu Aye, Inc. v. City of Hialeah. ${ }^{152}$ Plaintiffs asserted that the court would find no compelling state interest to justify immunization requirements. ${ }^{153}$ However, the court rejected Plaintiffs' argument. ${ }^{154}$ The Caviezel court found that Babalu Aye had established that "the general proposition that a law that is neutral and of general applicability need not be justified by a compelling governmental interest even if the law has the incidental effect of burdening a particular religious practice." ${ }^{\prime 55}$ Applied to Plaintiffs' argument, the court found that the state's mandatory school vaccination program was "neutral and of general applicability," so it did not need to be justified by a compelling governmental interest. ${ }^{156}$

Plaintiffs' second argument asserted that the holding in Jacobson was limited only to smallpox vaccinations. ${ }^{157}$ The Caviezel court quickly dispensed with this argument by looking to Zucht, which upheld a state statute requiring vaccination for school attendance without mentioning smallpox. ${ }^{158}$

The Caviezel court also analyzed cases that found that the Free Exercise Clause does mandate an exception to compulsory

\footnotetext{
150. Id. (citing McCarthy, 212 F. Supp. 2d at 949-50; Boone, 217 F. Supp. $2 d$ at 952-53).

151. Id. (quoting Sherr, 672 F. Supp. at 88).

152. Id. (citing Church of the Lukumi Babalu Aye, Inc. v. City of Hialeah, 508 U.S. 520 (1993)).

153. Id.

154. Id.

155. Id. (quoting Babalu Aye, 508 U.S. at 531).

156. Id. (citing Boone v. Boozman, 217 F. Supp. 2d 938, 953 (E.D. Ark. 2002), appeal dismissed sub nom. McCarthy v. Ozark Sch. Dist., 359 F.3d 1029 (8th Cir. 2004)).

157. Id. at 285 .

158. Id. (citing Zucht v. King, 260 U.S. 174, 175 (1922)).
} 
vaccinations. ${ }^{159}$ The court found two federal district courts within the Second Circuit that had implicitly held that "the First Amendment does provide a religious exemption to mandatory inoculation." 160 However, the court noted that neither case had discussed "whether the First Amendment in fact provides this right," nor had they "mention[ed] any of the relevant case law from the Supreme Court." "161 Based on its analysis, the Caviezel court found that "the free exercise clause of the First Amendment does not provide a right for religious objectors to be exempt from New York's compulsory inoculation law."162

\section{b. Phillips v. City of New York}

Following Caviezel, there has been one more meaningful case regarding the issue of religious exemptions for mandatory vaccinations: Phillips v. City of New York. ${ }^{163}$ Plaintiffs Nicole Phillips and Fabian Mendoza-Vaca both received religious exemptions from New York's mandatory vaccination program for their children. ${ }^{164}$ However, their children were excluded from school whenever there was a report of a vaccine-preventable disease. ${ }^{165}$ They sued, claiming the vaccination program denied their children the constitutional right to free exercise of religion. ${ }^{166}$ The district court quickly dismissed the First Amendment claim after citing favorably to Jacobson, Caviezel, and Sherr. ${ }^{167}$

On appeal, the Second Circuit Court of Appeals dispensed with the claim almost as quickly. ${ }^{168}$ Initially, the Second Circuit claimed that Jacobson had not addressed the free exercise of religion because, at the time, the states were not yet bound by the First Amendment through

\footnotetext{
159. Id. at 284 .

160. Id. (citing Moses v. Bayport Bluepoint Union Free Sch. Dist., No. 05CV3808, 2007 WL 526610, at *6 (E.D.N.Y. Feb. 13, 2007); Lewis v. Sobol, 710 F. Supp. 506, 518 (S.D.N.Y. 1989)).

161. Id.

162. Id. at 285 .

163. Phillips v. City of New York, 27 F. Supp. 3d 310 (E.D.N.Y. 2014) (holding that Free Exercise Clause does not provide a right to exemption from vaccination laws), aff'd, 775 F.3d 538 (2d Cir. 2015); Phillips v. City of New York, 775 F.3d 538, 543 (2d Cir. 2015) (agreeing with the Fourth Circuit that mandatory vaccination as a condition for admission to school does not violate the Free Exercise Clause).

164. Phillips, 27 F. Supp. 3d at 311.

165. Id.

166. Id. at 312 .

167. Id. at 312-13 (citing Jacobson v. Massachusetts, 197 U.S. 11, 11 (1905); Caviezel, 739 F. Supp. 2d at 285; Sherr v. Northport-East Northport Union Free Sch. Dist., 672 F. Supp. 81, 88 (E.D.N.Y. 1987)).

168. Phillips v. City of New York, 775 F.3d 538, 543 (2d Cir. 2015).
} 
incorporation. ${ }^{169}$ Therefore, the court did not believe that Jacobson controlled the free exercise claim. ${ }^{170}$ Despite this initial finding, the court then cited Prince and Babalu Aye, ${ }^{171}$ agreeing with the Fourth Circuit in Workman that "mandatory vaccination as a condition for admission to school does not violate the Free Exercise Clause." ${ }^{\prime 172}$ The Second Circuit found that "New York could constitutionally require that all children be vaccinated in order to attend public school. [However,] New York law goes beyond what the Constitution requires by allowing an exemption for parents with genuine and sincere religious beliefs.",173 Therefore, although the Supreme Court has not explicitly ruled on the issue, two circuit courts of appeals - the Second and Fourth - have held that mandatory vaccinations without religious exemptions do not violate the Free Exercise Clause.

\section{Removing the Religious Exemption from K.S.A. Section $72-5209$}

Would Not Violate the Free Exercise Clause

Removing the religious exemption from K.S.A. section 72-5209 would not violate the Free Exercise Clause of the First Amendment. As the district court in Caviezel pointed out, the Supreme Court has yet to rule explicitly that mandatory vaccinations without religious exemptions do not violate the Free Exercise Clause. ${ }^{174}$ However, the Second and Fourth Circuits, as well as two federal district courts in Arkansas, have determined that the Free Exercise Clause does not require religious exemptions for mandatory vaccinations. ${ }^{175}$ Only two federal district courts have taken the contrary view and, in doing so, neither actually analyzed case law from the Supreme Court that held that the First Amendment does provide a right to a religious exemption. While neither

\footnotetext{
169. Id. (citing Cantwell v. Connecticut, 310 U.S. 296, 303 (1940)).

170. Id.

171. Id. ("[A] parent 'cannot' claim freedom from compulsory vaccination for the child more than for himself on religious grounds. The right to practice religion freely does not include liberty to expose the community or the child to communicable disease or the latter to ill health or death." (quoting Prince v. Massachusetts, 321 U.S. 158, 166-67 (1944)); "[A] law that is neutral and of general applicability need not be justified by a compelling governmental interest even if the law has the incidental effect of burdening a particular religious practice." (quoting Church of the Lukumi Babalu Aye, Inc. v. City of Hialeah, 508 U.S. 520, 531 (1993))).

172. Id. (citing Workman v. Mingo Cty. Bd. of Educ., 419 F. App'x 348, 353-54 (4th Cir.

173. Id.

174. Caviezel v. Great Neck Pub. Sch., 739 F. Supp. 2d 273, 283 (E.D.N.Y. 2010), aff'd, 500 F. App'x 16 (2d Cir. 2012).
} 2011)).

175. See supra Part IV.B.1.b. 
the Tenth Circuit nor any district court in any of the states that comprise the Tenth Circuit have addressed the issue, the issue appears to be wellsettled within two circuits: compulsory vaccination laws do not violate the Free Exercise Clause.

\section{Religious Exemptions Are Not Mandated by the Substantive Due Process Clause}

\section{Circuit Courts Have Held that the Substantive Due Process Clause Does Not Require Religious Exemptions}

Parents have also challenged mandatory vaccinations with substantive due process arguments. The Due Process Clause of the Fourteenth Amendment provides that no State shall "deprive any person of life, liberty, or property, without due process of law," "176 thus providing "heightened protection against government interference with certain fundamental rights and liberty interests."177 "To determine whether an asserted right is a fundamental right subject to strict scrutiny under the Due Process Clause, a court must (1) consider whether the asserted right is deeply rooted in the Nation's history and tradition; and (2) require a careful description of the asserted liberty interest." "[D]etermining that a person has a 'liberty interest' under the Due Process Clause does not end the inquiry; whether [an individual's] constitutional rights have been violated must be determined by balancing his liberty interests against the relevant state interests." ${ }^{179}$ In a case in which the "State infringes on a fundamental constitutional right, strict scrutiny applies; otherwise, the state need only have a legitimate purpose." "180 Case law demonstrates that there is no fundamental interest in the plaintiffs' claims and that statutes rationally further a state interest: public health and safety.

First, in Boone, Cynthia Boone filed suit on behalf of her daughter when her daughter was suspended from school for having not received a

\footnotetext{
176. Boone v. Boozman, 217 F. Supp. 2d 938, 955 (E.D. Ark. 2002) (quoting U.S. Const. amend XIV, § 1), appeal dismissed sub nom. McCarthy v. Ozark Sch. Dist., 359 F.3d 1029 (8th Cir. 2004).

177. Workman, 419 F. App'x at 355 (quoting Washington v. Glucksberg, 521 U.S. 702, 720 (1997)).

178. Id. (quoting Glucksberg, 521 U.S. at 720-21).

179. Boone, 217 F. Supp. 2d at 955-56 (quoting Cruzan ex rel. Cruzan v. Dir., Mo. Dep't of Health, 497 U.S. 261, 279 (1990)).

180. Id. at 956 (quoting Glucksberg, 521 U.S. at 728) (emphasis in original).
} 
required vaccination. ${ }^{181}$ Boone claimed this violated her daughter's substantive due process rights and pointed out that "the right to refuse medical treatment is assumed to be a part of liberty protected under the Due Process Clause." "182 However, the district court found that the issue was not whether the child or parent could refuse medical treatment, but "whether the special protection of the Due Process Clause includes a parent's right to refuse to have her child immunized before attending public or private school where immunization is a precondition to attending school."," The court stated that "[t]he Nation's history, legal traditions, and practices answer with a resounding 'no.",184 The court noted that "the Supreme Court has acknowledged that a state may require school children to be immunized" and cited Zucht, Jacobson, and Prince. ${ }^{185}$ The court concluded by stating that "[i]t is apparent from these cases, and from a century of the nation's experience, that requiring school children to be immunized rationally furthers the public health and safety."186 The plaintiff made a last ditch argument, claiming her daughter had the fundamental right to a free and appropriate public education, but the court easily noted that "it [has been] firmly established that the right to an education . . . is not a fundamental right or liberty." "187

Next, in $P J$, the facts did not include parental refusal of mandatory school vaccinations, but rather parental refusal of cancer treatment for their child. ${ }^{188}$ Although the facts do not involve mandatory vaccination, the general principles are relevant to this discussion.

When analyzing the plaintiffs' Due Process claim, the $P J$ court noted that the Supreme Court held that "the Due Process Clause of the Fourteenth Amendment protects the fundamental right of parents to make decisions concerning the care, custody, and control of their children." I89 It also noted that the Tenth Circuit has "never specifically recognized or defined the scope of a parent's right to direct her child's medical care, [but] we do not doubt that a parent's general right to make decisions concerning the care of her child includes, to some extent, a

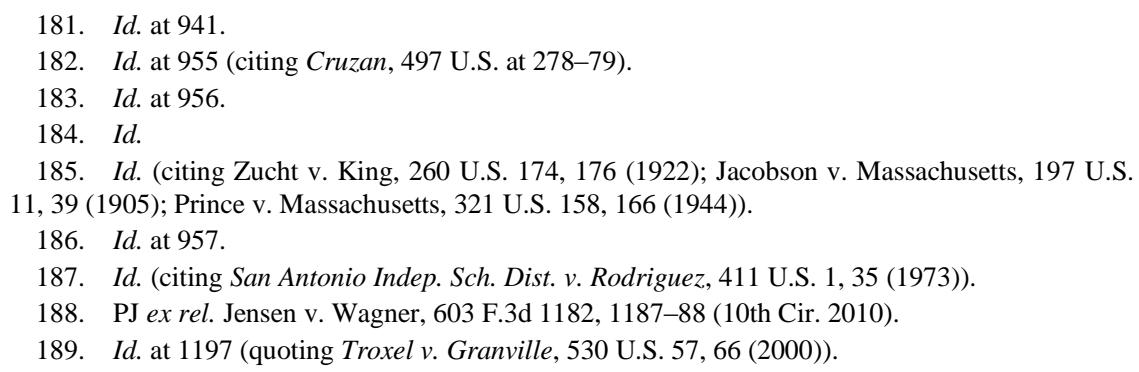


more specific right to make decisions about the child's medical care."190 Therefore, the $P J$ court believed that "the Due Process Clause provides some level of protection for parents' decisions regarding their children's medical care." 191 The court cited Prince, noting that "[t]he Supreme Court has long recognized, however, that parental rights, including any right to direct a child's medical care, are not absolute."192 "Accordingly, when a child's life or health is endangered by her parents' decisions, in some circumstances a state may intervene without violating the parents' constitutional rights." 193 Based on PJ, the Tenth Circuit would likely find that a state statute requiring immunizations prior to school would not unconstitutionally infringe on a parent's due process rights because the state may intervene when a child's health is endangered by his parent's decisions.

When Workman appealed her substantive due process claim to the Fourth Circuit, the court quickly concluded that she failed to demonstrate that the statute violated her rights. ${ }^{194}$ It agreed with the Boone court that the right to refuse to immunize a child before public school is not fundamental. ${ }^{195}$ The court went on to cite Prince, Zucht, and Jacobson, stating that "the Supreme Court has consistently recognized that a state may constitutionally require school children to be immunized."196 Therefore, the court concluded that Workman had failed to demonstrate that the statute violated her Due Process rights. ${ }^{197}$

When Caviezel was appealed to the Second Circuit, the plaintiffs asserted a substantive due process claim. ${ }^{198}$ The court immediately stated that the challenge was defeated by Jacobson. ${ }^{199}$ The plaintiffs argued that Jacobson was wrongly decided, but the court dismissed that claim, noting that the Supreme Court continues to cite it approvingly. ${ }^{200}$

The Eastern District of New York's decision in Phillips was similar.

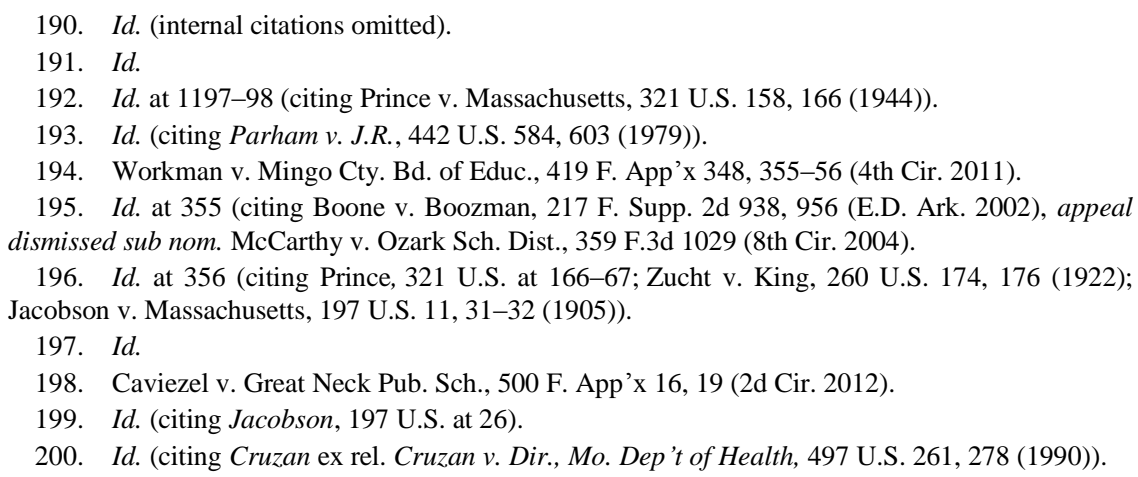


The court simply stated that "the Second Circuit has found that Jacobson flatly defeats any [substantive due process] claims" and cited to Caviezel. $^{201}$ At the Second Circuit, the claim got even less traction. ${ }^{202}$ The court concluded its minimal analysis by stating that the "[p]laintiffs" substantive due process challenge to the mandatory vaccination regime is ... no more compelling than Jacobson's was more than a century ago." ${ }^{203}$ Citing Jacobson, the Second and Fourth Circuits are convinced that there is no colorable substantive due process challenge to mandatory vaccinations. Taken with its analysis in $P J$, the Tenth Circuit would likely agree.

2. Removing the Religious Exemption from K.S.A. Section 72-5209 Would Not Violate the Substantive Due Process Clause

Removing the religious exemption from K.S.A. section 72-5209 would not violate the Substantive Due Process Clause of the First Amendment. The Second and Fourth Circuits are convinced that Jacobson crushes any such claim. Additionally, the Tenth Circuit has recognized that Prince stands for the proposition that parental rights, including any right to direct a child's medical care, are not absolute. Therefore, it is likely that if a religious objection to a compulsory vaccination program were presented to the Tenth Circuit, the court would find that even if the parent had a fundamental right, the state would have a compelling interest in the public health and safety.

\section{PROPOSED EXEMPTION METHODS}

The constitutionality of a mandatory vaccination program without a religious exemption provides the foundation necessary to propose a change to Kansas's mandatory vaccination program. There is adequate case law to support the proposition that the removal of Kansas's religious exemption would not violate the Free Exercise or the Due Process Clauses. Therefore, the next question is: what options are available to Kansas legislators? Should Kansas provide only a medical exemption or recognize a religious/philosophical exemption as well? This Comment will deal with arguments for and against each, concluding that Kansas

\footnotetext{
201. Phillips v. City of New York, 27 F. Supp. 3d 310, 313 (E.D.N.Y. 2014) (citing Caviezel, 500 F. App'x at 19), aff'd, 775 F.3d 538 (2d Cir. 2015).

202. Phillips v. City of New York, 775 F.3d 538, 542 (2d Cir. 2015).

203. Id. (citing Caviezel, 500 F. App'x at 19).
} 
should provide a medical exemption only.

\section{A. States Should Provide Only a Medical Exemption}

The strictest method of dealing with Kansas's religious exemption is to remove it completely in favor of a medical-only exemption. This proposal makes good sense for a variety of reasons, such as medical, legal, and systemic purposes.

\section{A Medical-Exemption-Only Program Would Best Protect Our \\ Children}

A medical-exemption-only program would reduce the number of exempt children, which in turn would "reduce the chances of outbreaks, and protect the largest possible number of children against disease."204 For that reason, there are several supporters of a medical-only exemption from compulsory vaccination. The American Medical Association (AMA), a group that has "promoted scientific advancement, improved public health, and invested in the doctor and patient relationship" since 1847, supports this limited exemption. ${ }^{205}$ On June 8, 2015, the AMA published a news release entitled "AMA Supports Tighter Limitations on Immunization Opt Outs." ${ }^{206}$ The release asserted that the only way to address the re-emergence of vaccine-preventable diseases in the United States requires that states move toward barring all non-medical exemptions to immunization mandates. ${ }^{207}$ Accordingly, the AMA "will seek more stringent state immunization requirements to allow exemptions only for medical reasons."208 The AMA recommends that states determine which vaccinations will be mandatory for admission to school and then grant medical exemptions only for those vaccinations. ${ }^{209}$

Individual proponents of medical-only exemptions speak out as well. Perhaps most passionate is Paul Offit, M.D., the director of the Vaccine

204. Dorit Rubinstein Reiss, Thou Shalt Not Take the Name of the Lord Thy God in Vain: Use and Abuse of Religious Exemptions from School Immunization Requirements, 65 HASTINGS L.J. 1551,1590 (2014).

205. Our History, AM. MED. Ass'N, http://www.ama-assn.org/ama/pub/about-ama/ourhistory.page? (last visited Mar. 27, 2016).

206. AMA Supports Tighter Limitations on Immunization Opt Outs, AM. MED. Ass'N (June 8, 2015), http://www.ama-assn.org/ama/pub/news/news/2015/2015-06-08-tighter-limitationsimmunization-opt-outs.page.

207. Id.

208. Id.

209. Id 
Education Center and an attending physician in the Division of Infectious Diseases at The Children's Hospital of Philadelphia. ${ }^{210}$ His passion likely derives from personal experience:

I was a young attending physician at the Children's Hospital of Philadelphia in 1991 during a massive measles epidemic - one that occurred almost 30 years after the invention of a measles vaccine. The outbreak centered on two fundamentalist churches in the city-Faith Tabernacle and First Century Gospel-which didn't believe in medical care. None of the children of church members was vaccinated. Among members of those two churches, 486 people were infected and six died from measles. The virus also spread to the surrounding community. Among non-church members, 938 people were infected and three died. The nine who died were all children. Church members had made a decision for their own children as well as those with whom their children had come in contact. ${ }^{211}$

He spoke out against more than just religious exemptions from vaccinations, but the crux of his argument was that "[c]hildren whose parents hold certain religious beliefs shouldn't be afforded less protection than other children." 212

Another proponent is Professor Tony Yang, Associate Professor in the Department of Health Administration and Policy at George Mason University. In his recent article in The Fiscal Times, he discussed the interesting results of his own and other studies concerning vaccinations exemptions. $^{213}$ He discussed a study conducted in 1999, which showed that people who are exempted are more likely to acquire measles. ${ }^{214}$ The study analyzed the differences in the relative risk of contracting measles among children who were vaccinated and those who were exempted. ${ }^{215}$ Results showed that individuals who were exempt were "35 times more likely on average to contract measles." 216 Yang also stated that the data showed that "if the proportion of [children that were exempted] increased, so would the number of measles cases among the whole

210. Paul A. Offit, MD, THE CHILDREN's HoSP. OF PHILA., http://www.chop.edu/doctors/offitpaul-a\#.Vcu8H_lViko (last visited Mar. 27, 2016).

211. Paul A. Offit, End Religious Exemption, PHILly.com (May 10, 2013), http://articles.philly.com/2013-05-10/news/39144680_1_child-abuse-neglect-first-century-gospel.

212. Id.

213. Yang, supra note 46.

214. Id.

215. Id.

216. Id 
population."217 In conclusion, he posed the question "[s]o could eliminating religious or personal belief exemptions curb outbreaks?"218 His answer? Look to Mississippi and West Virginia who have not seen a case of measles since the early 1990s. ${ }^{219}$

Finally, Anthony Schlaff, M.D., M.P.H., professor of public health and community medicine and director of public health programs at the Tufts School of Medicine, recently published an article in Tufts Medicine magazine. Schlaff's article claimed that religious exemptions for vaccines endanger us all. ${ }^{220}$ Schlaff begins by stating that " $[t]$ he measles epidemic in the western United States [in 2015] provides a good reminder that it is time to end the religious exemption for vaccination." ${ }^{221}$ His first and most significant point was that:

[W]e need to understand that government requires vaccination not to protect the individual, but to protect the community. Vaccines have failure rates - that is, what gives me and my family protection is not that I was vaccinated, but that everybody was. Despite the failure rate, enough of the community is immune so the disease cannot find room to spread. Combine the failure rate with a high-enough refusal rate, however, and the disease can spread, and even those who are immunized are at risk. ${ }^{22}$

\section{Religious Exemptions Are Unconstitutional}

Several legal reasons suggest that a medical-exemption-only program is best. This Comment proposes that removing the religious exemption is constitutional because it would not violate the Free Exercise and Due Process Clauses. However, others go so far as to propose that maintaining the religious exemption is unconstitutional because religious exemptions to mandatory vaccination programs violate the Establishment and Equal Protection Clauses. ${ }^{223}$

The Establishment Clause of the First Amendment states that "Congress shall make no law respecting an establishment of

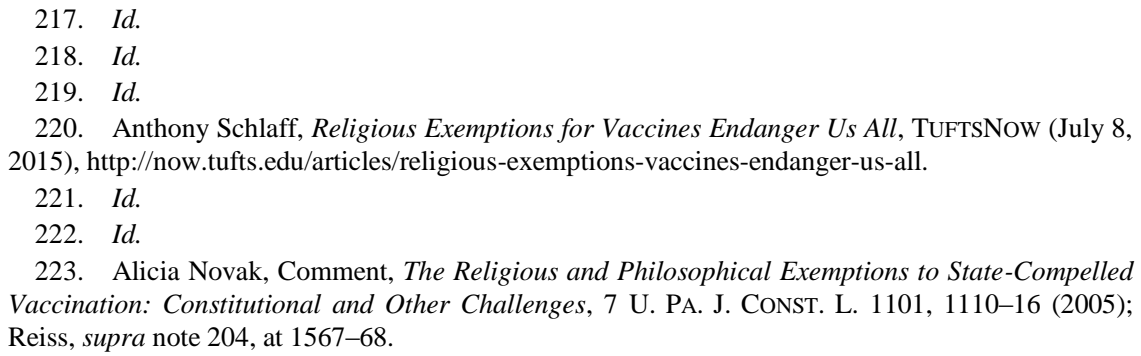

223. Alicia Novak, Comment, The Religious and Philosophical Exemptions to State-Compelled Vaccination: Constitutional and Other Challenges, 7 U. PA. J. ConST. L. 1101, 1110-16 (2005); Reiss, supra note 204, at 1567-68. 
religion . ..."224 At a minimum, this ensures that "[n]either a state nor the Federal Government . . . can pass laws which aid one religion, aid all religions, or prefer one religion over another." 225 In a comment that she wrote while a law student at the University of Pennsylvania Law School, Alicia Novak points out that opponents of a religious exemption contend that it improperly advances religion. ${ }^{226}$ The Supreme Court uses the Lemon test to determine the constitutionality of a statute challenged under the Establishment Clause: ${ }^{27}$

In order for a statute to be deemed constitutional under the test, it must satisfy the following three requirements: (1) the legislature must have had a secular purpose for adopting the enactment in question; (2) the primary effect of the law to be scrutinized must be one that neither advances nor inhibits religion; and (3) the statute must not result in an excessive entanglement of government with religion. ${ }^{228}$

Novak suggests that "[t]wo out of the three tests that states use to determine an applicant's eligibility for religious exemption fail under one or more of the prongs of the Lemon test." 229 She proposes that:

[t]hose states that require an applicant to belong to an 'organized,' 'recognized,' or 'established' religion employ an exemption test that likely violates both the second and third prongs because such statutes can be construed to 'advance' certain recognized religions while 'inhibiting' the practice of other, non-recognized faiths. Additionally, such statutes result in 'excessive' government entanglement with religion.

Novak also argues that the religious exemptions "violate the Equal Protection Clause because they discriminate against people who have unrecognized or unestablished religious beliefs against vaccination."231 The Equal Protection Clause prohibits the state from discriminating against individuals of suspect classes. ${ }^{232}$ Based on the Supreme Court's

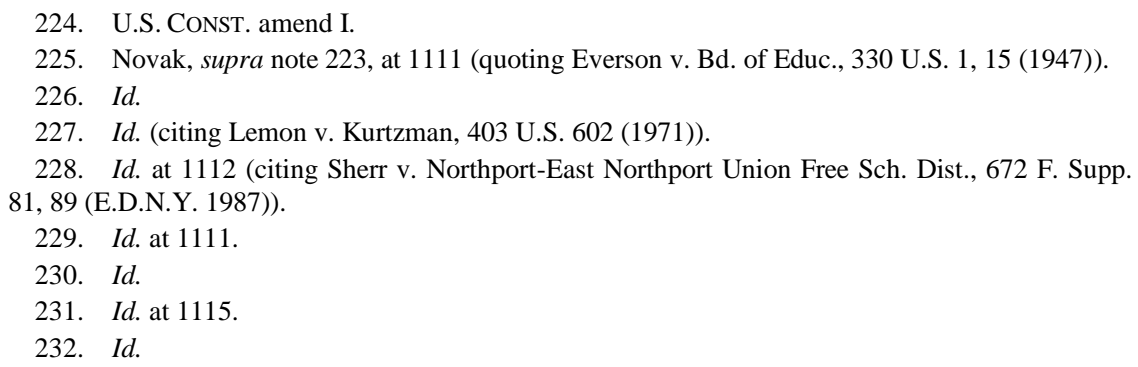


definition of a suspect class, ${ }^{233}$ Novak suggests that a court could find that individuals belonging to "unrecognized religious groups" are members of a suspect class because "they historically have been excluded by statutes that provide privileges or protections for members of certain established religious groups." ${ }^{234}$ As support, she cites Dalliv. Board of Education, in which the Supreme Judicial Court of Massachusetts found that "a state exemption for objectors who believed in 'recognized church[es] or religious denomination[s]' violated the Equal Protection Clause by giving preferential treatment to certain groups while ignoring others who have sincere, though unrecognized, religious objections." 235 Further, Novak points to Brown v. Stone, where the Mississippi Supreme Court held that "religious exemption policies violate the Equal Protection Clause because they 'discriminate against the great majority of children whose parents have no such religious convictions." "236

Novak provides Kansas's legislators more reasons to remove the religious exemption for mandatory vaccinations. As if protecting children was not reason enough to remove a religious exemption, actually having a religious exemption potentially violates both the Free Exercise and the Equal Protection Clauses.

\section{Religious Exemptions Are Systemically Broken}

Aside from constitutional issues with the religious exemption, there are also systemic issues explaining why opponents of religious exemptions are afraid for their children. For his article, Dorit Rubinstein Reiss, Professor of Law at the University of California's Hastings College of Law, went to anti-vaccination websites and read online posts by parents about using a religious exemption in their favor. ${ }^{237}$ The comments suggested that the real concern among parents is safety, and religion was just being used to "evade the obligation to vaccinate." 238

233. Id. ("The Supreme Court has defined a suspect class as a group 'saddled with such disabilities, or subjected to such a history of purposeful unequal treatment, or relegated to such a position of political powerlessness as to command extraordinary protection from the majoritarian political process."” (quoting San Antonio Indep. Sch. Dist. v. Rodriguez, 411 U.S. 1, 28 (1973))).

234. Id.

235. Id. (quoting Dalli v. Bd. of Educ., 267 N.E.2d 219, 220 (Mass. 1971)) (alterations in original).

236. Id. at 1115-16 (quoting Brown v. Stone, 378 So. 2d 218, 223 (Miss. 1979)).

237. Reiss, supra note 204, at 1584.

238. Id. at 1585-86 (including online post: "Should I be concerned that when my child enters 
There are several different ways contributors recommended to evade vaccination. The first way is for a person to claim that they followed a religion, even if they did not. ${ }^{239}$ Reiss included posts from parents saying they had used Christian Science and Catholicism effectively to receive an exemption without actually adhering to those religions. ${ }^{240}$ The second way to evade vaccination is to support a fake religion. ${ }^{241}$ One parent supported a religion based on Alphabiotics and then encouraged others to join for the sole purpose of evading vaccinations. ${ }^{242}$ A donation was required. ${ }^{243}$ The third way to evade was simply to lie. ${ }^{244}$ It seems that the first two ways Reiss mentions are lying as well, yet he makes the distinction. ${ }^{245}$ Reiss even references posts of atheists admitting to using religious exemptions to evade vaccinations. ${ }^{246}$ It seems improperly using religion to evade vaccinations is becoming a more common practice among opposed parents.

Reiss also provides an in-depth review of "Major Religions That Support Vaccinations" and discovers that "Even Sects Opposed to Modern Medicine Do Not Prohibit Vaccines."247 He provides evidence that Judaism, Islam, and Christianity, in which he included Catholics, Methodists, Lutherans, Mormons, Episcopalians, and Presbyterians, all actually support vaccinations. ${ }^{248}$ Additionally, he provides evidence that

\footnotetext{
school the religious exemption may no longer 'be allowed'?? I have a 13 month old and the more research I do, the more and more certain I become that I do not want to vaccinate. Should I go ahead and complete the steps for religious exemption?? My thoughts are if they ever do make it MANDATORY I would be grandfathered in. We live in Virginia. Thanks for your guidance.").

239. Id. at 1586 .

240. Id. (including online posts: "I am sure there will be exemptions allowed: Medical and Religious for sure! There has to be!!!! Note [sic] hard to find Bible verses to prohibit immunizations. Check out the verses that Christian Scientist use. I am not a CS but I used these verses to qualify for religious exemption for my 3 sons .... grade school thru [sic] college. No problem!!!!"; "I am one of the administrators for the page here in Michigan and obtained a religious exemption within my Catholic organization. I am not Catholic but they accepted it.”).

241. Id.

242. Id. at 1586-87 ("[P]ossible solution for religious exemption people- join the Alphabiotic alignment unification church and be exempt. [J]ust find a local alphabiotist office and join for minimal donation and you are in.").

243. Id.

244. Id. at 1587 .

245. Id.

246. Id. ("I filed a religious exemption in VA and no one batted an eye or questioned my beliefs. I'm actually an atheist but it's the only exemption option, aside from medical in VA. Once I was asked by a nurse at the dr.'s office about my religion but just told her that I believe religion is a personal thing and I don't like to discuss it.").

247. Id. at $1573-83$.

248. Id. at $1573-82$.
} 
smaller groups, such as Jehovah's Witnesses and Christian Scientists, although they do not support vaccinations, do not actually prohibit vaccinations among their members. ${ }^{249}$

Reiss' analysis raises some significant questions regarding Kansas's religious exemption. K.S.A. section $72-5209$ provides a religious exemption for a child who is "an adherent of a religious denomination whose religious teachings are opposed to [vaccinations]," ${ }^{, 50}$ yet Reiss provided evidence that most religious denominations are not actually opposed to vaccinations. Furthermore, Reiss revealed that parents are actually helping each other evade vaccinations using religious exemptions. So are Kansas parents lying? School officials worry that is the case so that they can claim a religious exemption. ${ }^{251}$

\section{Problems With a Medical-Exemption-Only Program}

Others see potential problems with eliminating non-medical exemptions. One argument is that a medical-exemption-only program will result in a loss of parental control. ${ }^{252}$ This argument centers on the idea that "[a] specific child might have special needs. In the normal state of affairs, a parent would know their child's situation best and would passionately advocate for that child's interest. The best way to protect the child, usually, is to give the parent the autonomy to manage the child."253 This argument directly conflicts with Prince. Prince clearly stated in dicta that " $[\mathrm{t}]$ he right to practice religion freely does not include liberty to expose the community or the child to communicable disease or the latter to ill health or death." ${ }^{254}$ While, in most situations, parents know what is best for their child, when they refuse to vaccinate their child based on religious beliefs, they are demonstrating that they are no longer making decisions that are in the best interest of the child.

Another argument against the medical-exemption-only program is that this program results in perceptions of state coercion. ${ }^{255}$ Such

\footnotetext{
249. Id. at 1582-83.

250. KAN. STAT. ANN. § 72-5209(b)(2) (West 1994).

251. Brad Cooper \& Dawn Bormann, Kansans Debate Vaccine Exemption, ThE KANSAS CiTY STAR (Jan. 18, 2012, 5:00 AM), http://www.kansascity.com/news/local/article300521/Kansansdebate-vaccine-exemption.html ("Kansas school officials have long worried that some families simply fib and claim religious reasons.").

252. Reiss, supra note 204, at 1591.

253. Id. at 1591-92.

254. Prince v. Massachusetts, 321 U.S. 158, 166-67 (1944).

255. Kevin Hooker, Comment and Note, Exemptions to Vaccine Mandates: The Problem and
} 
perceptions could break down the long-term sustainability and acceptability of vaccination programs. ${ }^{256}$ The argument proposes that "[d]espite the fact that the majority of people vaccinate themselves and comply with mandates, there are many people who are uncomfortable with the idea of the mandates themselves." ${ }^{257}$ Supporters of this argument believe that "people may be increasingly distrustful and wary of what they see as more government intrusion into their decision making." 258 This "could lead to an increase in opposition or suspicion to vaccine mandates that could do more harm than good."259 While this argument raises concerns about state coercion, it likely only appeals to an extreme minority who are already distrustful of government intrusion.

\section{B. Alternatives to a Medical-Exemption Only Program}

On the other side of the argument is a program that maintains the religious exemption but uses alternatives to reduce the number of exemptions used. Several alternatives have been offered.

The first alternative is financial incentives and disincentives. ${ }^{260}$ The simplest form of implementation would be a tax. ${ }^{261}$ To incentivize parents to vaccinate their children, they could be offered a refund when filing their federal income tax return. ${ }^{262}$ Conversely, a disincentive would be a tax on those who fail to comply with the vaccination mandate. ${ }^{263}$ However, an advocate of this scheme, Kevin Hooker, brings to light a problem with such an alternative-the cost to the government. $^{264}$ Applying this alternative to the 2012-13 kindergarten population for Kansas, Kansas would be providing a refund to approximately 36,664 families based on kindergarten alone. It hardly seems feasible for Kansas to support such an incentive program.

Another alternative Hooker presents is to make exemptions more difficult to obtain. ${ }^{265}$ He generally references studies that show that

\footnotetext{
Possible Remedies, 14 Hous. J. Health L. \& POL’y 263, 290 (2014).

256. Id.

257. Id.

258. Id.

259. Id.

260. Id. at 293.

261. Id.

262. Id.

263. Id. at 294.

264. Id. at 294-95.

265. Id. at 295 .
} 
"states with more stringent exemption requirements show a noticeable difference in the percentage of the population who obtain exemptions." "266 This alternative has also been supported by Professor Reiss, who specifically talks about "Tightening Religious Exemptions."267 In doing so, Reiss specifically references New York, which requires a sincere religious opposition to vaccinations. ${ }^{268}$ Under this method, the person seeking the exemption must demonstrate to the court that the person's asserted beliefs are sincerely held. ${ }^{269}$ "Evidence a court might use in a sincerity analysis includes (1) whether the adherent acted inconsistently with the belief at issue; (2) whether the adherent materially gained by masking secular beliefs with a religious veneer; and (3) the religion's history and size." ${ }^{270}$ Yet, as previously discussed, such a method of granting religious exemptions could have potential issues when analyzed against the Establishment Clause because it improperly advances religion. ${ }^{271}$

Hooker's final alternative is to educate parents. ${ }^{272}$ He referenced one study that measured the effect of education on health care workers receiving an influenza vaccination. ${ }^{273}$ According to the study, there was an increase in vaccination rates from 13 percent to 37 percent when health "facilities used education, availability, and reminders." $274 \mathrm{He}$ referenced another four-year study that showed that one hospital's vaccination rates for health care workers increased from 27 percent to 52 percent when the hospital conducted an "educational campaign that focused on the need for vaccinations, vaccine efficacy, affordability, and reminders." 275 Hooker suggests that similar methods could be used in conjunction with other alternatives to educate the public as a whole. ${ }^{276}$

Unfortunately, education does not seem to be a highly effective alternative. It took the hospital in Hooker's article four years to raise its flu vaccination rates by 25 percent. Nevertheless, the Kansas Department of Health and Environment is already working to educate

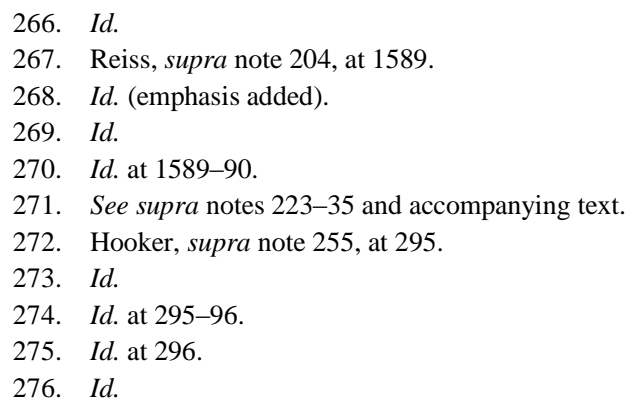


parents on the necessity of vaccinating their children. ${ }^{277}$ Although this campaign is an excellent tool, it does not seem that such a campaign is the aggressive solution Kansas desperately needs. Kansas needs help from its legislators.

\section{The Best Method for Kansas}

For a variety of reasons, a medical-exemption-only program is the best method for Kansas to follow. Most importantly, as evidenced by Mississippi and West Virginia, states without a religious exemption have the highest immunization rates and the lowest number of cases of vaccine-preventable diseases. That alone should be enough of an incentive for Kansas legislators to remove a religious exemption to mandatory vaccinations, especially when Kansas has vaccination rates in the bottom one-third of the nation and very high numbers of cases of vaccine-preventable diseases. The numbers, and the professionals, indicate that a medical-exemption-only program is the best method to protect the state's children.

Other methods have been recommended as alternatives to removing the religious exemption, but those hardly seem feasible for Kansas. Whether it is providing financial incentives or "tightening" the religious exemption, Kansas is likely to encounter more trouble than it would by simply removing the exemption entirely. Financial incentives would place a significant burden on Kansas's budget, and tightening the exemption with a sincerity test could result in constitutional challenges under the Establishment Clause or Equal Protection Clause. On the other hand, there is significant evidence to suggest that if a medicalexemption-only program was challenged as unconstitutional under the Free Exercise or Substantive Due Process Clause, the statute would be upheld.

Finally, for those individuals who believe that a religious exemption is necessary to provide parents religious freedom with their children, Reiss' article is enlightening. Many parents are using the religious exemption as a loophole - not for its intended purpose. School officials in Kansas already believe that parents are lying to claim religious exemptions. ${ }^{278}$ That becomes even clearer when Reiss points out that

277. Kansas Immunization Program, KANSAs DePARTMENT OF HeAlth AND ENVIRONMENT, http://www.kdheks.gov/immunize/index.html (last visited Mar. 28, 2016).

278. Cooper \& Bormann, supra note 257 ("Kansas school officials have long worried that some families simply fib and claim religious reasons.”). 
"no major religion" prohibits vaccination. ${ }^{279}$ It seems there are ample reasons that Kansas should adopt a similar vaccination program as Mississippi, West Virginia, and California and eliminate all non-medical exemptions.

\section{CONCLUSION}

In recent years, Kansas legislators have been headed in the wrong direction by trying to add a philosophical exemption through House Bill 2094 and Senate Bill 67. As all the evidence presented in this Comment indicates, more exemptions create a higher risk of vaccine-preventable diseases. Kansas legislators should propose a bill that removes religious exemptions from K.S.A. section 72-5209. By having a medicalexemption-only mandatory vaccination program, exemptions will decrease and vaccination rates will increase so that Kansas school children will be much better protected against vaccine-preventable diseases.

279. Reiss, supra note 203, at 1573. 